\title{
PERILAKU PENGGUNA AIR SUNGAI DENGAN KELUHAN KESEHATAN KULIT PADA MASYARAKAT SEKITAR SUNGAI PANGAMBANGAN BANJARMASIN
}

\author{
User River Water Behavior With Competitive Health Complaint In The Community Around The \\ Pangambmangan River Banjarmasin
}

Fahrurazi, Yeni Riza, Erwin Ernadi

Fakultas Kesehatan Masyarakat UNISKA MAB Banjarmasin

Email :fahrurazi.fkm@gmail.com

\begin{abstract}
The results of river water quality monitoring from 2013 to 2015 resulted that the Martapura River and Barito River included in severe pollutant status. The purpose of this research is to know the behavior of river water users and the utilization of health services with complaints of skin health by the community around the Banjarmasin mining river. The research method used is descriptive with cross sectional approach. The sample is done by purposive sampling. The instrument in this research is using questionnaire. Analysis of this data using Chi Square statistical test. The results of the research show that there is no relationship between knowledge about the use of river water with skin health complaints $(p$-value $=0.130)$. There is no correlation between attitude toward river water usage with skin health complaint ( $p$-value $=1,000)$. There is no correlation between the action in the use of river water with skin health complaint ( $p$-value $=0,130)$. Most people do not experience skin health complaints that is as much 89 people $(96,7 \%)$. Suggestions that can be given that is for responder increase awareness in maintaining and conserving river water, the awareness to behave healthy life with the basic provisions of environmental management.
\end{abstract}

Keywords : Behavior, Health Service, river

\begin{abstract}
Abstrak
Hasil pemantauan kualitas air sungai oleh Badan Lingkungan Hidup Kota Banjarmasin tahun 2013, 2014, dan 2015 diperoleh hasil bahwa Sungai Martapura dan Sungai Barito termasuk dalam status cemar berat. Tujuan dari penelitian ini adalah mengetahui perilaku pengguna air sungai dan pemanfaatan pelayanan kesehatan dengan keluhan kesehatan kulit oleh masyarakat sekitar sungai pengambangan Banjarmasin. Metode penelitian yang digunakan deskriptif dengan pendekatan cross sectional. Sampel dilakukan secara purposive sampling. Instrumen dalam penelitian ini yaitu menggunakan kuesioner. Analisa data ini menggunakan uji statistik Chi Square. Hasil penelitian menunjukan bahwa tidak ada hubungan antara pengetahuan tentang penggunaan air sungai dengan keluhan kesehatan kulit $(p$-Value $=0,130)$. Tidak ada hubungan antara sikap terhadap penggunaan air sungai dengan keluhan kesehatan kulit $(p$-value $=1,000)$. Tidak ada hubungan antara tindakan dalam penggunaan air sungai dengan keluhan kesehatan kulit $(p$-value $=0,130)$. Sebagian besar masyarakat tidak mengalami keluhan kesehatan kulit yaitu sebanyak 89 orang $(96,7 \%)$. Saran agar lebih meningkatkan kesadaran dalam menjaga dan melestarikan air sungai, agar masyarakat berperilaku hidup sehat dengan ketentuan-ketentuan pokok pengelolaan lingkungan hidup.
\end{abstract}

Kata Kunci : Perilaku, Pelayanan Kesehatan, Sungai 


\section{PENDAHULUAN}

Hasil pemantauan kualitas air sungai oleh Badan Lingkungan Hidup Kota Banjarmasin tahun 2013, 2014, dan 2015 diperoleh hasil bahwa Sungai Martapura dan Sungai Barito termasuk dalam status cemar berat. Tahun 2015 tim pemantauan Air Badan Lingkungan Kota Banjarmasin telah memantau sebagian Sungai Barito yang merupakan sungai lintas kota dan provinsi atau disebut sebagai sungai utama, dan sebagian Sungai Martapura yang merupakan sungai lalu lintas kabupaten/kota dan merupakan sungai strategis dimana sebagian segi tersebut termasuk dalam wilayah kota Banjarmasin. Sungai tersebut sangat penting keberadaanya untuk menunjang kebutuhan hidup sehari-hari masyarakat sekitarnya dan merupakan bahan baku PDAM (Badan Lingkungan Hidup Kota Banjarmasin, 2015).

Secara epidemiologis ada keterkaitan yang erat antara masalah air bersih dengan penyakit kulit, maka oleh sebab itu dengan adanya tingkat cakupan air bersih yang tinggi dapat menurunkan angka penyakit kulit. Dalam kaitan dengan hal tersebut maka seharusnya air bersih yang digunakan harus memenuhi persyaratan kualitas yang telah tetapkan. Persyaratan kualitas tersebut telah tertuang dalam Permenkes No 492/2010 tentang syarat-syarat dan kualitas air bersih (Depkes RI, 2010). Berdasarkan survei pendahuluan ternyata sebagian besar masyarakat pengambangan menggunakan air sungai pengambangan untuk mandi, mencuci pakaian maupun peralatan dapur, buang air besar/kecil, termasuk mencuci kendaraan bermotornya.

Berdasarkan survei pendahuluan, sebagian besar masyarakat pengambangan menggunakan air sungai untuk mandi, mencuci pakaian maupun peralatan dapur, buang air besar/kecil, termasuk mencuci kendaraan bermotornya. Hal ini dikarenakan kebiasaan yang sudah turun temurun dan mereka menganggap sudah kebal terhadap penyakit yang diakibatkan oleh penggunaan air sungai, padahal seluruh masyarakatnya sudah mengetahui bahwa air sungai yang mereka gunakan sudah tercemar berat dan tidak layak untuk digunakan. Walaupun demikian, masyarakat tetap memanfaatkan air sungai tersebut. Masyarakat berpendapat bahwa air sungai yang mereka gunakan

sering pasang surut dan mengalir sehingga kuman, virus, dan bakteri yang ada disungai sudah larut dan tidak mempengaruhi kesehatan. Penyakit kulit yang dialami oleh masyarakat Kelurahan Pengambangan sungai berupa gatal, bintik-bintik merah ,nyeri, panas/ hangat, kulit bersisik, namun tidak tertutup kemungkinan hanya disebabkan oleh penggunaan air bersih saja, tetapi terdapat kemungkinankemungkinan lain seperti alergi makanan, kekurangan gizi, sanitasi lingkungan dan kesehatan perorangan.

Dari data Dinas Kesehatan Kota Banjarmasin tahun 2015, kasus penyakit kulit di wilayah kerja Puskesmas 9 November yaitu sebanyak 1.267. Oleh karena itu, maka penulis meneliti hubungan domain "Perilaku Pengguna Air Sungai Dengan Keluhan Kesehatan Kulit Pada Masyarakat Sekitar Sungai Pengambangan Kota Banjarmasin"

\section{BAHAN DAN METODE}

Jenis penelitian ini menggunakan metode survey Analitik dengan rancangan penelitian yaitu Cross Sectional. Populasi dalam penelitian ini adalah semua masyarakat di sekitar sungai Pengambangan yang berkunjung dan berobat di Puskesmas 9 November dengan keluhan kesehatan kulit dengan jumlah 1.267. Instrumen yang dipergunakan dalam penelitian ini yaitu kuesioner dengan wawancara untuk mengidentifikasi perilaku (pengetahuan, sikap dan tindakan), dan keluhan kesehatan kulit. Variabel bebas dalam penelitian ini adalah perilaku (pengetahuan, sikap dan tindakan), sedangkan variabel terikat dalam penelitian ini adalah keluhan kesehatan kulit. Analisis data dalam penelitian ini menggunakan uji chi square dengan tingkat kepercayaan $95 \%$.

\section{HASIL DAN PEMBAHASAN}

Kecamatan Banjarmasin Timur didirikan sejak tahun 1965 dengan membawahi dua kelurahan yakni : Kelurahan Pengambangan dan Kelurahan Benua Anyar. Luas wilayah kerja seluruhnya $2,88 \mathrm{Km}^{2}$, terdapat 1 Puskesmas yaitu puskesmas 9 Nopember

\section{Analisis Univariat}


Tabel 1. Distribusi Frekuensi Pengetahuan, Sikap, Tindakan dan Keluhan Kesehatan Kulit

\begin{tabular}{lcc}
\hline Variabel & $\mathbf{n}$ & $\mathbf{\%}$ \\
\hline Pengetahuan & & \\
\hline Kurang Baik & 76 & 82,6 \\
\hline Baik & 16 & 17,4 \\
\hline Sikap & & \\
\hline Negatif & 7 & 7,6 \\
\hline Positif & 85 & 92,4 \\
\hline Tindakan & & \\
\hline $\begin{array}{l}\text { Menggunakan Air } \\
\text { Sungai }\end{array}$ & 76 & 82,6 \\
\hline $\begin{array}{l}\text { Tidak Menggunakan } \\
\text { Air Sungai }\end{array}$ & 16 & 48,1 \\
\hline $\begin{array}{l}\text { Keluhan Kesehatan } \\
\text { Kulit }\end{array}$ & & \\
\hline Ya & 3 & 3,3 \\
\hline Tidak & 89 & 96,7 \\
\hline Total & $\mathbf{9 2}$ & $\mathbf{1 0 0}$ \\
\hline
\end{tabular}

Berdasarkan tabel 1 menunjukkan bahwa sebagian besar pengetahuan responden adalah kurang baik yaitu sebesar $76(82,6 \%)$, sikap responden sebagian besar adalah positif yaitu sebesar 85 (92,4\%). Sebagian besar responden menggunakan air sungai yaitu $76(82,6 \%)$, dan sebagian besar tidak mengalami keluhan kesehatan kulit yaitu 89 (96,7\%).

\section{Analisis Bivariat}

\section{Hubungan Pengetahuan dengan Keluhan Kesehatan Kulit pada Masyarakat Sekitar Sungai Pangambangan Banjarmasin}

Tabel 2 menunjukan bahwa 76 responden yang berpengetahuan kurang baik terdapat 75 orang $(63,3 \%)$ yang tidak mengalami keluhan kesehatan kulit, dan yang mengalami keluhan kesehatan kulit yaitu sebanyak 1 orang (2,5\%), sedangkan responden yang mempunyai pengetahuan baik sebanyak 16 responden, yang tidak mengalami keluhan kesehatan kulit yaitu sebanyak 14 orang (15,5\%), dan yang mengalami keluhan kesehatan kulit yaitu sebanyak 2 orang $(0,5 \%)$. Hasil analisis statistik dengan uji Chi Square, nilai 0,130>0,05 berarti Ho diterima. Uji statistik menunjukkan Ha ditolak yaitu tidak ada hubungan yang bermakna antara pengetahuan dengan keluhan kesehatan kulit pada masyarakat sekitar sungai Pangambangan, ini dikarenakan pengetahuan masyarakat dalam penggunaan air sungai dan dampak dari penggunaan air sungai sudah baik.

Menurut Lawrence Green perilaku itu dipengaruhi oleh 3 (tiga) faktor yaitu faktor presdiposisi, faktor pemungkin, dan faktor pendorong. Faktor presdiposisi salah satunya mencakup pengetahuan, sikap, kepercayaan, keyakinan, nilai-nilai dan sebagainya. Disimpulkan bahwa perilaku seseorang atau masyarakat tentang kesehatan ditentukan oleh pengetahuan, sikap, kepercayaan, tradisi dan sebagainya dari orang atau masyarakat yang bersangkutan (Notoadmodjo, 2010).

Pada penelitian ini menunjukan bahwa mayoritas responden yang menjawab pernyataan pengetahuan yang benar adalah pada pernyataan "membuang sisa-sisa makanan atau kegiatan rumah tangga dapat mencemari dan menurunkan kualitas air sungai" yang, diikuti dengan membuang sampah kesungai dapat menyebabkan pencemaran air sungai. Itu artinya konsep ini benar-benar dipahami oleh masyarakat sekitar sungai pangambangan seperti diungkapkan oleh salah satu responden yang menyatakan bahwa pengetahuan masyarakat sendiri tentang membuang sisa-sisa makanan atau kegiatan rumah tangga dapat mencemari dan menurunkan kualitas air sungai sebenarnya sudah tahu kalau itu tidak baik tetapi tetap saja mereka lakukan karena kebiasaan yang sudah turun temurun sampai sekarang sehingga menjadi pola pikir dan pilihan sungai untuk kebutuhan rumah tangga.

Banyak masyarakat yang berpendapat bahwa membuang sisa-sisa makanan atau kegiatan rumah tangga langsung kesungai pasti akan langsung larut dan terbawa oleh aliran sungai sehingga air sungai yang mereka gunakan sudah bersih dan semua kuman, bakteri dan virus juga sudah ikut terlarut dibawa oleh air sungai sehingga tidak menimbulkan berbagai penyakit yang diakibatkan oleh penggunaan air sungai. Hasil penelitian ini sejalan dengan Siti Rahmayani, dkk (2014) tentang hubungan pengetahuan dengan frekuensi kejadian penyakit kulit didapatkan hasil (p.value $=1,000)$ yang menunjukan tidak ada hubungan antara pengetahuan 
Tabel 2. Perilaku Pengguna Air Sungai dengan Keluhan Kesehatan Kulit pada Masyarakat Sekitar Sungai Pangambangan Banjarmasin

\begin{tabular}{|c|c|c|c|c|c|c|c|}
\hline \multirow{3}{*}{ Variabel } & \multicolumn{4}{|c|}{ Keluhan Kesehatan Kulit } & & & \multirow{3}{*}{ p.value } \\
\hline & \multicolumn{2}{|c|}{ Ya } & \multicolumn{2}{|c|}{ Tidak } & \multicolumn{2}{|c|}{ Jumlah } & \\
\hline & $\mathrm{n}$ & $\%$ & $\mathrm{n}$ & $\%$ & $\mathrm{~N}$ & $\%$ & \\
\hline \multicolumn{8}{|l|}{ Pengetahuan } \\
\hline Kurang Baik & 1 & 1,3 & 75 & 98,7 & 76 & 100 & 0,130 \\
\hline Baik & 2 & 12,5 & 14 & 87,5 & 16 & 100 & \\
\hline \multicolumn{8}{|l|}{ Sikap } \\
\hline Negatif & 0 & 0 & 7 & 100 & 7 & 100 & 1,000 \\
\hline Positif & 3 & 3,5 & 82 & 96,5 & 85 & 100 & \\
\hline \multicolumn{8}{|l|}{ Tindakan } \\
\hline Menggunakan Air Sungai & 1 & 1,3 & 75 & 98,7 & 76 & 100 & 0,130 \\
\hline Tidak Menggunakan Air Sungai & 2 & 12,5 & 14 & 87,5 & 16 & 100 & \\
\hline
\end{tabular}

dengan frrekuensi kejadian penyakit kulit. Pengetahuan yang diteliti adalah pengetahuan mengenai penggunaan air sungai Kuantan. Ini menunjukan bahwa pengetahuan yang kurang belum tentu bisa menyebabkan tingginya frrekuensi kejadian penyakit kulit, hal ini dimungkinkan karena pengetahuan tersebut hanya sekedar tahu, sehingga pengetahuan tersebut belum dicerminkan pada tindakan sehari-hari. Penelitian oleh Rachmasari (2013), mengenai faktor-faktor yang berhubungan dengan kejadian dermatitis pada PETI didapatkan $\mathrm{p}$ value $=1,000>0,005$, sehingga secara statistik menunjukan bahwa tidak terdapat hubungan yang bermakna antara pengetahuan dengan kejadian dermatitis. Hal ini dikarenakan seseorang yang tahu belum tentu bisa menerapkan apa yang sudah diketahuinya tersebut dalam kehidupan sehari-hari.

\section{Hubungan Sikap dengan Keluhan Kesehatan Kulit pada Masyarakat Sekitar Sungai Pangambangan Banjarmasin}

Tabel 2 menunjukan bahwa 7 responden bersikap negatif, yang tidak mengalami keluhan kesehatan kulit yaitu sebanyak 7 orang $(100 \%)$, dan tidak ada responden yang mengalami keluhan kesehatan kulit $(0 \%)$, sedangkan 85 responden bersikap positif yang tidak mengalami keluhan kesehatan kulit yaitu sebanyak 82 orang $(96,5 \%)$, dan yang mengalami keluhan kesehatan kulit yaitu sebanyak 3 orang $(3,5 \%)$. Hasil analisis statistik dengan uji Chi Square, nilai 1,000 > 0,05 berarti Ho diterima. Uji statistik menunjukkan Ha ditolak yaitu tidak ada hubungan yang bermakna antara sikap dengan keluhan kesehatan kulit pada masyarakat sekitar sungai Pangambangan.

Menurut Notoadmodjo (2010), sikap merupakan reaksi atau respon yang masih tertutup dari sesorang terhadap suatu stimulus atau objek. Sikap juga merupakan kesiapan atau kesediaan untuk bertindak dan juga merupakan pelaksanaan motif tertentu. Dalam penelitian ini, pernyataan responden dari pernyataan positif yang ada di kuesioner, yang paling dominan sangat setuju yaitu terhadap pernyataan "sampah tidak boleh dibuang kesungai". Itu artinya kesadaran responden untuk tidak membuang sampah kesungai sudah sangat bagus, namun pada faktanya masih banyak responden yang membuang sampah kesungai, karena di sebagian besar di pinggiran sungai Pangambangan belum ada upaya dari pemerintah untuk memberikan sarana dan prasarana untuk pembuangan sampah. Selain itu, masyarakat berpendapat bahwa sampah yang mereka buang kesungai akan ikut larut dan sungai akan tetap bersih.

Pernyataan negatif dari kuesioner ada 5 pernyataan, dan dari 5 pernyataan tersebut dapat diketahui bahwa pernyataan responden yang paling mendominasi pernyataan sangat tidak setuju adalah "penggunaan air sungai dapat menyebabkan adanya penyakit kulit". Dari pernyataan responden menunjukan bahwa selama ini masyarakat sekitar sungai tidak mempermasalahkan penggunaan air sungai dalam aktifitas sehari-hari, karena sebagian 
masyarakat menganggap air sungan tidak memberikan dampak pada kesehatan kulit.

\section{Hubungan Tindakan dengan Keluhan Kesehatan Kulit pada Masyarakat Sekitar Sungai Pangambangan Banjarmasin}

Tabel 2 menunjukan bahwa 76 responden menggunakan air sungai, yang tidak mengalami keluhan kesehatan kulit sebanyak 75 orang $(98,7 \%)$, dan yang mengalami keluhan kesehatan kulit yaitu sebanyak 1 orang (1,3\%), sedangkan 16 responden tidak menggunakan air sungai, yang tidak mengalami keluhan kesehatan kulit yaitu sebanyak 14 orang $(87,5 \%)$, dan yang mengalami keluhan kesehatan kulit yaitu sebanyak 2 orang (12,5\%). Hasil analisis statistik dengan uji Chi Square, nilai 0,130 > 0,05 berarti Ho diterima. Uji statistik menunjukkan Ha ditolak yaitu tidak ada hubungan yang bermakna antara tindakan dengan keluhan kesehatan kulit pada masyarakat sekitar sungai pangambangan.

Menurut Notoadmodjo (2010), sikap adalah kecenderungan untuk bertindak (praktik). Sikap belum tentu terwujud dalam tindakan perlu faktor lain, yaitu antara lain adanya fasilitas atau sarana dan prasarana. Praktik atau tindakan ini dapat dibedakan menjadi tiga tingkatan menurut kualitasnya, yaitu praktik terpimpin (guided response) apabila subjek atau seseorang telah melakukan sesuatu tetapi masih tergantung pada tuntutan atau menggunakan panduan, praktik secara mekanisme (mechanism) apabila subjek atau seseorang telah melakukan sesuatu hal secara otomatis maka disebut praktik atau tindakan mekanis, dan adopsi (adoption) adalah suatu tindakan atau praktik yang sudah berkembang. Artinya apa yang dilakukan tidak sekedar rutinitas atau mekanisme saja, tetapi sudah dilakukan modifikasi, atau tindakan atau perilaku yang yang berkualitas.

Dari hasil penelitian, dapat diketahui bahwa masyarakat yang menggunakan air sungai sebagai kebutuhan sehari-hari merupakan tindakan yang dapat mencemari sungai terutama dalam hal limbah domestik. Secara umum dapat dikatakan bahwa masyarakat pengguna air sungai pangambangan melakukan tindakan pencemaran sungai. Kebiasaan mandi bagi masyarakat di sekitar sungai Pangambangan. juga ada kesamaan dengan mencuci dan melakukan kegiatan rumah tangga lainnya disungai. Satu hal yang dapat mengubah kegiatan masyarakat ini yaitu jika air asin dimusim kemarau yang dialami masyarakat sekitar sungai Pengambangan. Hasil survei membuktikan bahwa masyarakat juga menggunakan air sungai sebagai tempat sampah dikarenakan tidak adanya tempat pembuangan sementara yang dekat dari tempat tinggal, tidak ada petugas kebersihan yang datang untuk membawa sampah yang telah dikumpulkan sehingga masyarakat lebih memilih membuang sampah kesungai. Selain itu, banyak masyarakat yang kesulitan untuk membayar PDAM setiap bulannya dikarenakan sebagian besar masyarakat hanya pedagang yang hasil pendapatan mereka setiap bulan tidak memenuhi kebutuhan sehari-hari mereka, apalagi untuk membayar PDAM sehingga mereka lebih memilih menggunakan air sungai untuk keperluan sehari-hari selain untuk minum karena air sungai sangat berguna dan dapat menurunkan pengeluaran mereka setiap bulannya.

Limbah domestik yang dibuang pada badan sungai mengandung sampah padat berupa tinja dan cair berupa sampah rumah tangga dan beberapa sifat utama, antara lain mengandung bakteri, yang dapat menyebabkan penularan penyakit, mengandung bahan organic dan padatan tersupensi sehingga BOD biasanya tinggi, mengandung padatan organik dan anorganik yang mengendap di dasar perairan dan menyebabkan DO rendah, mengandung bahan terapung dalam bentuk suspense sehingga mengurangi kenyamanan dan menghambat laju fotosintesis (Supriharyono, 2002).

\section{KESIMPULAN DAN SARAN}

Berdasarkan hasil penelitian diperoleh data tentang perilaku masyarakat yang meliputi: pengetahuan, sikap dan tindakan menunjukan bahwa tidak ada hubungan antara pengetahuan tentang penggunaan air sungai dengan keluhan kesehatan kulit $(p$-value $=0,130)$. Tidak ada hubungan antara sikap terhadap penggunaan air sungai dengan keluhan kesehatan kulit ( $p$-value $=1,000)$. Tidak ada hubungan antara tindakan dalam penggunaan air 
sungai dengan keluhan kesehatan kulit ( $p$-value= $0,130)$. Sebagian besar masyarakat tidak mengalami keluhan kesehatan kulit yaitu sebanyak 89 orang $(96,7 \%)$.

\section{DAFTAR PUSTAKA}

Badan Lingkungan Hidup, 2015. Data Data Kuliatas Air Banjrmasin Tahun 2015. Badan Lingkungan Hidup Banjarmasin. Banjarmasin.

Dinas Kesehatan, 2015. Laporan Tahunan Data Kesakitan. Banjarmasin: Dinas Kesehatan

Depkes RI., 2010. Permenkes RI No. 492/MENKES/PER/IV/2010. Tentang Persyaratan Kualitas Air Minum. Depkes RI, Jakarta.

Notoatmodjo, Soekidjo., 2010. Promosi Kesehatan dan Ilmu Perilaku. Jakarta: Rineka Cipta

Puskesmas 9 November, 2015. Laporan Tahunan Puskesmas 9 November. Banjarmasin : Puskesmas 9 November.
Rachmasari, N., 2013. Faktor-faktor yang berhubungan dengan kejadian dermatitits kontak iritan pada pengrajin logam di desa Cepogo, Kecamatan Cepogo Kabupaten Boyolali. Vol. 2, No. 1. [Online]. https://media.neliti.com/media/publications /18782-ID-faktor-faktor-yang-berhubungandengan-kejadian-dermatitis-kontak-iritanpada-pen.pdf. [diakses tanggal 08 juli 2014].

Rahmayani, Siti., Rahmalia, Siti., Dewi, Yulia Irvani., 2014. JOM PSIK. Hubungan Pengetahuan Dan Perilaku Dengan Frekuensi Kejadian Penyakit Kulit Pada Masyarakat Pengguna Air Kuantan, Vol. 1, No. 2. [Online]. https://media.neliti.com/media/publications /183490-ID-hubungan-pengetahuan-danperilaku-dengan.pdf.

Supriharyono, 2002. Pelestarian Sumber Daya Tanah dan Air. Yogyakarta: Andi Offset. 